\title{
MENINGKATKAN AKTIVITAS DAN HASIL BELAJAR MATEMATIKA MELALUI STRATEGI PEMBELAJARAN TAPPS BERBASIS PENDEKATAN (STEM)
}

\author{
Meri Hari Yanni \\ Program Studi Pendidikan Matematika \\ STKIP Bumi Persada Lhokseumawe \\ Email: merihyanni@gmail.com
}

\begin{abstract}
ABSTRAK
Penelitian ini bertujuan untuk meningkatkan aktivitas dan hasil belajar siswa kelas VIII SMP Perguruan Islam Al-Ulum Terpadu Medan melalui strategi pembelajaran TAPPS berbasis pendidikan STEM. Metode penelitian, yakni penelitian tindakan kelas sebanyak dua siklus. Setiap siklus terdiri dari 4 tahap: perencanaan, pelaksanaan tindakan, observasi, dan refleksi. Teknik analisis data yang digunakan adalah model analisis deskriptif. Metode pengumpulan data yang digunakan adalah observasi dan tes. Hasil penelitian menunjukkan bahwa implementasi menggunakan startegi pembelajaran TAPPS berbasis pendidikan STEM dapat meningkatkan aktivitas belajar siswa VIII SMP Perguruan Islam AlUlum Terpadu Medan pada materi Bangun Ruang Sisi Datar. Hal ini ditunjukkan dengan persentase aktivitas kelompok siswa pada siklus I 50,71\% atau berada dalam kategori cukup baik, persentase aktivitas kelompok siswa pada siklus II $85,04 \%$ atau dalam kategori sangat baik. Dengan demikian, peningkatan aktivitas belajar siswa menggunakan startegi pembelajaran TAPPS berbasis pendidikan STEM juga dapat meningkatkan hasil belajar siswa. Hal ini ditunjukkan dengan persentase ketuntasan belajar pada siklus I 65,6255\% atau berada dalam kriteria sudah tuntas akan tetapi masih tergolong rendah dan persentase ketuntasan belajar pada siklus II 90,625\% atau berada dalam kriteria sudah tuntas. Simpulan dari penelitian ini adalah melalui penggunaan strategi pembelajaran TAPPS berbasis pendidikan STEM dapat meningkatkan aktivitas dan hasil belajar peserta didik.
\end{abstract}

Kata Kunci. strategi TAPPS, pendidikan STEM, aktivitas, hasil belajar siswa

\section{ABSTRACT}

This study aimed to improve the activity and learning outcome of the eighth grade students of Al-Ulum Islamic school Medan through the TAPPS learning strategy based on STEM education. The research method was a classroom action research as much as two cycles. Each cycle consisted of 4 stages: planning, action, observation, and reflection. The data analysis technique was a descriptive analysis model. Data collection methods were observation and tests. The results showed that the implementation of using the STEM-based TAPPS learning strategy could improve learning activity of the eighth grade student of Al-Ulum Islamic school Medan on the subject of geometry flat side (Bangun Ruang Sisi 
Datar). This was shown by the percentage of group activity of students in the cycle I was $50.71 \%$ or in a good category, the percentage of student group activity in the cycle II was $85.04 \%$ or in an excellent category. Thus, the enhancement of students' learning activity using the TAPPS learning strategy based on STEM education could also improve students' learning outcome. This was shown by the percentage of learning mastery in the cycle I was 65,6255\% or in the criteria of learning mastery was achieved but it was still classified as low and the percentage of learning mastery, in the cycle II was 90,625\% or in the criteria of leaening mastery was achieved. The conclusion of this study is the use of TAPPS-based STEM education learning strategy can improve the activity and learning outcome of students.

Keyword: TAPPS strategy,STEM education, activities, students' learningout come

\section{PENDAHULUAN}

Peningkatan mutu pendidikan merupakan salah satu upaya pemerintah dalam memajukan pendidikan serta mencerdaskan anak bangsa. Berbagai terobosan dan kebijakan serta upaya yang telah dilakukan pemerintah untuk meningkatkan mutu pendidikan sekolah secara nasional. Salah satu upaya dalam meningkatkan mutu pendidikan di sekolah adalah dengan meningkatkan kemampuan belajar siswa dan kualitas guru dalam mengajar.

Belajar, perkembangan dan pendidikan merupakan gejala yang berkaitan dengan pembelajaran. Belajar merupakan suatu proses yang dilakukan oleh siswa secara individu untuk memperoleh suatu perubahan tingkah laku yang baru terhadap hasil pengalaman dalam berinteraksi dengan lingkungannya (Slameto, 2003). Menurut Gagne (dalam Djamarah dan Zain, 2006) mengatakan bahwa belajar adalah suatu perubahan pada watak dan kapasitas manusia yang berlangsung selama suatu jangka waktu tertentu dan tidak hanya sekedar menganggap proses pertumbuhan semata.

Perkembangandan pembentukan karakter merupakan suatu proses yang dialami dan dihayati oleh individu siswa menuju tingkat kedewasaan sehingga memerlukan pengembangan keteladanan yang ditularkan melalui proses pembelajaran, sedangkan pendidikan merupakan kegiatan interaksi. Dalam kegiatan interaksi, pendidik bertindak dalam mendidik siswa sehingga segala tindakan dapat mengembangkan kemampuan dan aktivitas siswa menjadi lebih mandiri. Berdasarkan pendapat para ahli yang mendefiniskan belajar menggunakan kata "perubahan" yang berarti seseorang setelah belajar akan mengalami perubahan. Perubahan tersebut terdiri dari perubahan pola pikir, pengetahuan, paradigma, dan perilaku dalam penyelenggaraan belajar mengajar di dalam kelas sehingga menjadikan pembelajaran lebih berkualitas (Hamalik, 2009).

Berdasarkan hasil observasi yang dilakukan di SMP Perguruan Islam Al-Ulum Terpadu Medan ditemui bahwa pokok bahasan bangun 
ruang merupakan salah satu pokok pembahasan yang sulit untuk dipahami. Kesulitan ini dapat dilihat ketika siswa kurang memahami konsep bangun ruang, kesulitan dalam merancang dan menyelesaikan masalah terkait bangun ruang seperti merancang dan menunjukkan jaringjaring bangun ruang serta menghitung luas permukaan dan volume dari bangun ruang.

Oleh sebab itu, dari hasil wawancara dengan guru diperoleh bahwa aktivitas siswa dalam proses belajar masih tergolong rendah sehingga banyak dijumpai siswa yang masih memiliki nilai rendah, terutama pada materi bangun ruang. Permasalahan lainnya adalah penggunaan metode pengajaran oleh guru yang kurang tepat sehingga guru kurang bervariasi dalam mengajarkan matematika disekolah.

Beberapa dari guru umumnya masih menggunakan metode konvensional dalam menjelaskan materi dan membahas contoh soal bersama siswa. Pembelajaran konvensional merupakan pembelajaran yang menggunakan metode ceramah dan tanya jawab antar siswa dan guru dengan satu arah dimana guru berperan sebagai informasi dan siswa sebagai penerima informasi.

Menurut Sullivan dan Mclntosh (2001), proses pembelajaran melalui pendekatan konvensional lebih banyak didominasi oleh guru sebagai pentransfer ilmu sementara siswa lebih pasif sebagai penerima ilmu sehinga guru hanya mengajarkan penguasaan konsep-konsep tanpa memperhatikan kemampuan siswa. Dalam pelaksanaanya, siswa hanya menghafal konsep dan prinsip dari unsur-unsur yang terkandung dalam konsep tersebut sehingga memungkinkan terjadi kesalahan siswa dalam memahami pelajaran. Kondisi tersebut mengakibatkan kurang responnya siswa dalam mengikuti kegiatan pembelajaran dan juga mengakibatkan berkurangnya rangsangan terhadap aktivitas belajar siswa sehingga proses pembelajaran dengan menggunakan metode ini kurang efektif.

Aktivitas siswa selama proses belajar mengajar merupakan salah satu indikator yang sangat penting dalam proses pembelajaran. Hal ini diperkuat oleh pendapat Sardiman (2001) yang mengatakan bahwa belajar adalah berubah, berubah untuk mengubah tingkah laku maka tidak ada belajar kalau tidak ada aktivitas. Oleh sebab itu, dengan adanya aktivitas dalam kegiatan pembelajaran menandakan adanya keinginan siswa untuk belajar.

Aktivitas tersebut merupakan segala kegiatan yang dilakukan dalam proses interaksi guru dan siswa dalam rangka mencapai tujuan belajar sehingga terciptalah suasana belajar yang aktif. Keaktifan belajar siswa dapat meningkatkan motivasi belajar siswa, hal ini dikarenakan segala bentuk kegiatan dalam belajar seperti sikap menaruh perhatian siswa, sikap 
mau menanggapi, menghargai, ketekunan dan keaktifan siswa dalam pembelajaran sangat menentukan keberhasilan siswa dalam mencapai hasil belajar yang diinginkan (Darmodjo, 1991).

Hasil belajar siswa merupakan suatu kinerja yang diindikasikan sebagai suatu kemampuan yang telah diperoleh setelah menerima pengalaman belajarnya. Menurut Ahmadi dan Supriyono (2004), rendahnya hasil belajar siswa tidak hanya disebabkan oleh kelemahan belajar siswa tetapi juga disebabkan oleh sistem pengajaran yang kurang efisien, kurang efektif dan kurang memotivasi siswa dalam belajar.

Berdasarkan pendapat tersebut, hasil belajar siswa tidak hanya ditentukan dari kemampuan belajar siswa melainkan metode pengajaran yang diterapkan oleh guru. Oleh sebab itu, dilakukan variasi metode/strategi pembelajaran sehingga dengan adanya variasi dapat menimbulkan daya tarik siswa untuk menaruh perhatian terhadap pembelajaran serta memotivasi siswa untuk mencapai hasil belajar yang diinginkan.

Untuk mengatasi permasalahan yang telah dikemukakan diatas salah satunya adalah dengan menerapkan metode pembelajaran yang dapat membentuk kemampuan pemecahan masalah pada siswa dalam suasana pembelajaran yang demokratis sehingga dapat meningkatkan aktivitas dan hasil belajar siswa yaitu dengan menerapkan strategi pembelajaran
TAPPS (Thinking Aloud Pair Problem Solving) berbasis pendidikan STEM.

Strategi TAPPS (Thinking Aloud

Pair Problem Solving) berbasis pendidikan STEM merupakan gabungan antara model pembelajaran cooperative tipe Think Pair Share dan pendekatan Problem Solving yang kemudian dikemas dalam pendidikan STEM. Strategi ini merupakan suatu strategi pembelajaran pemecahan masalah pada kemampuan berfikir siswa, dimana strategi ini memberikan kesempatan kepada siswa untuk mencari jawaban dari permasalahan secara berkelompok yang diaplikasikan dalam kehidupan nyata/alam.

Menurut Ibrahim, dkk (2000), Strategi ini dilakukan dalam beberapa langkah pembelajaran yaitu terlebih dahulu siswa dikelompokkan berpasang-pasangan dengan peran yang berbeda satu sama lainnya yaitu sebagai problem solver dan listener. Selanjutnya setiap kelompok diberikan rangkaian permasalahan sehingga siswa yang berperan sebagai problem solver bertugas untuk mengungkapkan secara lisan dan jelas mengenai solusi dari masalah yang diberikan, sedangkan listener bertugas untuk menganalisis dan memberikan usulan jika terdapat pernyataan problem solver yang tidak sesuai atau tidak dimengerti.

Selanjutnya, problem solver dan listener saling bertukar peran untuk permasalahan berikutnya. Penggunaan pendidikan STEM dilakukaan pada 
saat pemecahan masalah yang mengaitkannya pada dunia nyata/ alam. Pada proses pemecahan masalah, digunakan teknik dalam pemecahan masalah yang kemudian digunakan teknologi dalam proses tersebut sehingga pada proses akhir diselesaikan dengan menggunakan konsep matematika.

Menurut Nurhadi dan Senduk (2003), Strategi ini memberikan kepada siswa waktu untuk berfikir dan merespon serta saling membantu satu sama lainnya dalam pemecahan masalah yang diberikan oleh guru dan diungkapkan secara lisan kepada teman yang lain. Hal penting yang dapat diperhatikan dalam strategi ini adalah guru tidak hanya melihat hasil yang diperoleh siswa melainkan guru melihat bagaimana suatu proses berfikir siswa dalam memecahkan masalah untuk mendapatkan hasil dan diungkapkan secara lisan dan jelas.

Selanjutnya, kelebihan dari penelitian ini adalah siswa dituntut untuk berfikir dan bertindak secara nyata dengan mengimplementasikan suatu masalah dalam dunia nyata sehingga pola berfikir siswa lebih terstruktur, dan melatih siswa dalam berdialog menyampaikan informasi dan penjelasan dari solusi permasalahan serta menghasilkan pemahaman materi yang lebih mendalam. Dengan demikian, Penelitian Strategi Pembelajaran TAPPS berbasis pendekatan STEM merupakan kebaharuan dari penelitian ini.

\section{METODE PENELITIAN}

Penelitian ini merupakan penelitian tindakan kelas (classroom action reseach) yang dilakukan sebanyak dua siklus di SMP Perguruan Perguruan Tinggi Islam AlUlum Terpadu Medan pada tahun ajaran 2015/2016. Setiap siklus terdiri dari 4 tahap yaitu perencanaan, pelaksanaan tindakan, observasi, dan refleksi. Instrumen yang digunakan pada penelitian ini adalah Rencana Pelaksanaan Pembelajaran (RPP), Lembar Kerja Kelompok (LKK), Lembar observasi aktivitas siswa secara individu maupun kelompok dan lembar soal postest.

Data yang diperoleh dianalisis secara kuantitatif dan kualitatif. Data hasil observasi dianalisis secara kualitatif, sedangkan data tes hasil belajar dianalisis secara kuantitatif dengan menggunakan teknik analisis deskriptif, yang terdiri atas: nilai ratarata (mean), nilai maksimum dan nilai minimum siswa yang diperoleh pada setiap siklus.

\section{HASIL PENELITIAN}

Pada kondisi awal, peneliti melakukan observasi melalui dokumentasi nilai matematika siswa sebelum menggunakan strategi TAPPS berbasis STEM. Hasil belajar siswa pada kondisi awal diperoleh nilai tertinggi 75 , nilai terendah 40 , dan nilai rata-rata 61,09. Dari hasil tersebut diperoleh persentase ketuntasan belajar siswa pada materi bangun ruang datar sebesar $46,875 \%$. 
Hasil tersebut belum sesuai dengan kriteria ketuntasan belajar siswa yaitu $65 \% \leq$ Persentase Penilaian Hasil dilakukan refleksi. Deskripsi hasil belajar siswa pada kondisi awal dapat $(\mathrm{PPH}) \leq 100 \%$. Oleh karena itu perlu dilihat pada tabel 1

Tabel. 1 Statistik Nilai Hasil Belajar Matematika

STATISTIK

SEBELUM

PERLAKUAN

SIKLUS I

SIKLUS II

\begin{tabular}{lccc}
\hline Nilai terendah & 40 & 60 & 70 \\
\hline Nilai tertinggi & 75 & 80 & 98 \\
\hline Nilai Rata-rata & 61,09 & 74,22 & 92 \\
\hline Jumlah Siswa yang tuntas & 13 & 21 & 30 \\
\hline Jumlah Siswa yang tidak tuntas & 19 & 11 & 2 \\
\hline Persentase ketuntasan belajar & $46,875 \%$ & $65,625 \%$. & $90,625 \%$ \\
\hline
\end{tabular}

Dari tabel 1 terlihat bahwa terjadi peningkatan hasil belajar siswa pada siklus I. Hal ini dapat dilihat dari nilai rata-rata hasil belajar siswa meningkat sebesar 74,22 dengan persentase ketuntasan belajar sebesar 65,625\%. Persentase ketuntasan belajar siswa pada siklus 1 dikatakan sudah tuntas, namun masih tergolong rendah dikarenakan banyaknya jumlah siswa yang tidak tuntas yaitu sebanyak 11 orang. Kondisis tersebut dikarenakan siswa masih kebingungan dalam menggunakan strategi TAPPS berbasis pendidikan STEM. Oleh karena itu, perlu dilakukan refleksi dan tindakan pada siklus II. Selanjutnya, nilai hasil belajar siswa kelas VIII pada siklus II sangat meningkat.
Dari hasil data di atas diperoleh nilai tertinggi 98, nilai terendah 70 , dan nilai rata-rata 92 sehingga diperoleh persentase ketuntasan belajar siswa dalam memahami materi bangun ruang sebesar 90,625\%. Pada siklus II, pemahaman siswa pada materi bangun ruang dengan menggunakan strategi TAPPS berbasis pendidikan STEM sudah sangat meningkat, hal ini dapat dilihat dari jumlah siswa yang memenuhi kriteria ketuntasan belajar sebanyak 30 siswa.

Penilaian aktivitas belajar siswa dilakukan melalui lembar observasi. Dari beberapa kegiatan aktivitas belajar siswa yang diamati di kelas, maka di kategorikan dalam 4 aspek aktivitas yang di akumulasi pada tabel 2

Tabel. 2 Kriteria Aktivitas Belajar Matematika

\begin{tabular}{cccc}
\hline \multirow{2}{*}{ No } & Aktivitas Siswa & Persentase kelas Siklus I & \multirow{2}{*}{ Persentase kelas Siklus II } \\
\hline 1 & Minat & $2,85 \%$ & $3,96 \%$ \\
\hline 2 & Perhatian & $1,81 \%$ & $3,59 \%$ \\
\hline 3 & Partisipasi & $1,58 \%$ & $3,65 \%$ \\
\hline 4 & Presentasi & $2,78 \%$ & $3,85 \%$ \\
\hline & Persentase kelompok & $50,71 \%$ & $85,04 \%$ \\
\hline & Kategori & Cukup baik & Sangat Baik \\
\hline
\end{tabular}


Pada tabel 2 dapat dilihat bahwa aktivitas siswa pada siklus I masih tergolong sangat rendah yaitu dengan diperolehnya persentase aktivitas kelompok siswa sebesar $50,71 \%$. Hal tersebut terjadi disebabkan kurang optimalnya proses pemahaman dan hasil belajar siswa dalam menggunakan strategi pembelajaran TAPPS berbasis pendidikan STEM. Berdasarkan pengamatan yang diperoleh peneliti bahwa rata-rata siswa masih belum memahami penjelasan guru terkait pelaksanaan dari strategi TAPPS berbasi pendidikan STEM, tidak mencatat rincian dari penjelasan guru dan pemahaman terhadap masalah masih sangat minim sehingga materi pelajaran belum dapat dipahami siswa dengan baik. Aktivitas siswa pada siklus II juga sudah menunjukkan nilai yang baik.

Dari analisis data diperoleh persentase aktivitas siswa sebesar $85,04 \%$. Pada siklus ini siswa sudah terlihat aktif dan mandiri dalam memahami dan mengaplikasikan suatu masalah dalam kehidupan seharihari/nyata. Kekompakkan siswa dalam kelompoknya juga sudah muncul, hal ini dapat di lihat dari saling mendukung dan berkerja sama dalam menyelesaikan masalah dan mempresentasikannya dengan sangat jelas sesuai perannya masing-masing.

\section{PEMBAHASAN}

Berdasarkan analisis data di atas maka dapat diketahui bahwa Strategi TAPPS berbasis pendidikan STEM dapat meningkatkan hasil belajar pada siswa kelas VIII SMP Perguruan Islam Al-Ulum Terpadu Medan. Hal ini didukung dengan pendapat Ibrahim, dkk (2000) yang mengemukakan bahwa Strategi TAPPS merupakan strategi pembelajaran dengan membentuk sebuah pasangan dalam satu kelompok yang berperan sebagai problem solver dan listener. Selanjutnya, setiap kelompok diberikan suatu rangkaian permasalahan yang kemudian diaplikasikan ke dalam kehidupan nyata dengan mengaitkan teknik dan teknologi serta matematika dalam rangkaian permasalahan tersebut. Menurut Wijaya, dkk (2015) pembelajaran dengan berbasis STEM dapat melatih kemampuan dan bakat siswa dalam dunia nyata sehingga melibatkan berbagai aktivitas siswa dalam penggunannya.

Berdasarkan hasil analisis data dapat ditemukan peningkatan pemahaman konsep bangun ruang bidang datar dan peningkatan aktivitas siswa. Hal ini, menandakan bahwa penerapan Strategi TAPPS berbasis pendidikan STEM dalam pembelajaran matematika pokok bahasan bangun ruang bidang datar dapat meningkatkan aktivitas belajar siswa dan hasil belajar matematika pada pokok bahasan bangun ruang bidang datar, karena pembelajaran lebih aktif, menyenangkan, memudahkan siswa untuk memahami materi yang ada dengan bertukar informasi bersama teman-teman sehingga menimbulkan inovasiinovasi terbaru, dan komunikatif antar pasangan satu kelompok serta lebih antusias dalam memahami permasalahan dan menemukan solusi dari masalah yang dihadapai.

Hasil penelitian ini juga sejalan dengan penelitian yang dilakukan oleh Widiyastuti, dkk (2014) dan Handayani, dkk (2014) yang 
menunjukkan bahwa kemampuan komunikasi matematika siswa yang belajar dengan menggunakan strategi pembelajaran TAPPS lebih baik daripada kemampuan komunikasi matematika siswa yang belajar dengan pembelajaran konvensional. Selanjutnya, Penelitian lainnya yang relevan terhadap penelitian ini adalah penelitian yang dilakukan oleh Permanasari (2016), yaitu pembelajaran berbasis pendidikan STEM dapat dikemas dalam model pembelajaran kooperatif sehingga dapat meningkatkan literasi sains, kreativitas, dan kemampuan pemecahan masalah.

Dengan demikian dapat diketahui bahwa, salah satu upaya untuk meningkatkan pemahaman konsep bangun ruang bidang datar mata pelajaran matematika pada siswa kelas VIII SMP Perguruan Islam Al-Ulum Terpadu Medan yaitu dengan menerapkan Strategi TAPPS berbasis pendidikan STEM. Penerapan Strategi TAPPS berbasis pendidikan STEM dapat menjadikan pembelajaran matematika pokok bahasan bangun ruang bidang datar menjadi lebih menyenangkan sehingga pemahaman siswa meningkat. Jadi, pembelajaran dengan penerapan Strategi TAPPS berbasis pendidikan STEM dapat meningkatkan hasil belajar matematika pada materi bahasan bangun ruang bidang datar bagi siswa kelas VIII SMP Perguruan Islam AlUlum Terpadu Medan.

\section{SIMPULAN}

Hasil penelitian dan pembahasan diperoleh kesimpulan bahwa penerapan strategi Thinking Aloud Pair Problem Solving (TAPPS) berbasis pendidikan STEM (Sains, Technology, Engineering, Mathematics) dapat meningkatkan aktivitas belajar siswa kelas VIII SMP Perguruan Islam Al-Ulum Terpadu Medan. Penerapan strategi TAPPS berbasis pendidikan STEM dalam kegiatan proses pembelajaran melatih siswa berperan aktif dan terampil dalam melakukan pemecahan masalah secara berpasangan dalam satu kelompok dengan terlebih dahulu menyusun langkah-langkah penyelesaian serta meningkatnya penguasaan siswa terhadap materi pembelajaran.

Dengan demikian, peningkatan aktivitas belajar siswa dengan menggunakan strategi Thinking Aloud Pair Problem Solving (TAPPS) berbasis pendidikan STEM mengakibatkan hasil belajar siswa ikut meningkat. Hal ini dapat dilihat dari meningkatnya nilai rata-rata siswa melebihi target indikator keberhasilan yang telah ditetapkan.

Berdasarkan simpulan diatas, peneliti memberikan saran yang berhubungan dengan penerapan Thinking Aloud Pair Problem Solving (TAPPS) berbasis pendidikan STEM dalam kegiatan proses pembelajaran yaitu (1) Pada saat menggunakan strategi TAPPS berbasis pendidikan STEM dalam proses pembelajaran, terlebih dahulu seorang guru menetapkan waktu dengan estimasi waktu yang sesuai dengan soal yang diberikan, (2) Sebelum membuat tes soal, terlebih dahulu guru memperhatikan tingkat kesulitas soal terhadap kemampuan siswa, (3) Pembentukan pasangan pada strategi TAPPS berbasis pendidikan STEM dilakukan secara acak dan dilakukan pergantian pasangan setiap pertemuan 
pembelajaran, hal ini bertujuan untuk meningkatkan komunikasi siswa dan saling membantu satu sama lainnya.

\section{DAFTAR PUSTAKA}

Ahmadi, A. dan Supriyono, W. (2004). Psikologi Belajar. Jakarta:Rhineka Cipta.

Djamarah, S. B dan Zain, A. (2006). Strategi Belajar Mengajar. Jakarta:Rhineka Cipta.

Darmojo. (1991). Mengajar Matematika. Jakarta:Erlangga.

Hamalik, Oemar. (2009). Perencanaan Pengajaran Berdasarkan Pendekatan Sistem. Jakarta : Bumi Aksara

Ibrahim, H. M., Rachmadiarti, F. dan Ismono. (2000). Pembelajaran Kooperatif. Surabaya:UNESAUniversitas Press.

Nurhadi dan Senduk. (2003). Psikologi Belajar. Jakarta:Rhineka Cipta.

Slameto. (2003). Belajar dan FaktorFaktor yang Mempengaruhinya. Jakarta:Rhineka Cipta.

Sardiman, A. M. (2001). Interaksi dan Motivasi Belajar Mengajar. Jakarta:PT. Raja Grasindo Persada.
Sullivan, R.L. dan Mclntosh, N. (2001). Delivering Efective Lectures. Bactimore Maryland:JHIEGO Coorporation.

Permanasari, Anna. (2016). STEM Education : Inovasi dalam Pembelajaran Sains. SNPS Universitas Sebelas Maret.

Handayani., Laely Suci, Syafriandi dan Mirna. (2014). Pengaruh Metode TAPPS Terhadap Kemampuan Komunikasi Matematika Siswa SMA. Jurnal Pendidikan Matematika, 3 (1)

Widiyastuti, Dini., Sri Elniati., Minora Longgom Nasution. (2014). Penerapan Strategi Thinking Aloud Pair Problem Solving (TAPPS) dalam Pembelajaran Matematika Kelas VIII SMPN 11 Padang. Jurnal Pendidikan Matematika, 3 (1)

Wijaya., Agusta Danang, Nila Karmila dan Mahmudah Rizqi Amalia. (2015). Implementasi Pembelajaran Berbasis STEM pada Kurikulum Indonesia. Proseding Seinar Nasional Fisika dan Aplikasinya Universitas Padjadjaran. 